\title{
Introduction
}

\section{John Dewey on Philosophy and Childhood}

\section{Maughn Gregory and David Granger}

John Dewey was not a philosopher of education in the now-traditional sense of a doctor of philosophy who examines educational ends, means, and controversies through the disciplinary lenses of epistemology, ethics, and political theory, or of agenda-driven schools such as existentialism, feminism, and critical theory. Rather, Dewey was both an educator and a philosopher, and he saw in each discipline reconstructive possibilities for the other, famously characterizing "philosophy ... as the general theory of education" (1985, p. 338). Dewey wanted each discipline to overcome its tendency to alienate knowledge and theory from experience and reconstruct itself as an enterprise aimed at personal and collective well-being.

That disciplinary ethos is articulated in this issue of Education and Culture by authors who, like Dewey, often work at the intersection of philosophy and education and who have considered the significance of children and childhood for both disciplines. ${ }^{1}$ Two interrelated, paradigmatic figures emerge from these essays, neither of which can be found directly in Dewey's writing, but neither of which, perhaps, would be articulated so widely or so compellingly today without him: the Child as Philosopher and the Philosopher as Child.

\section{The Philosopher as Child}

Proponents of the figure of the Philosopher as Child see the practice of philosophy, ideally, as involving a turn toward childhood. They identify certain characteristics of childhood, such as impulsiveness, somatic awareness, and cultural naïveté, as important correctives to the personal and cultural habits of adulthood that impede growth as they become hardened and nonadaptive-especially as these habits have been manipulated by commercial, religious, and political forces. ${ }^{2}$ Thus, Eric Anthamatten observes in his essay that "Dewey lean[s] toward the child as the source and reminder to teachers, adults, and philosophy itself that the great truth 
that must be pursued begins and ends with the 'live creature,' fully present"; and David Kennedy cites Dewey, telling us that "there is in the unformed activities of childhood and youth the possibilities of a better life for the community as well as for individuals" (1922, p. 99).

The authors in this issue consistently lament the fact that spontaneity, corporeality, and naïveté have become associated almost exclusively with childhood, and habit, rationality, constraint and erudition with adulthood. This historical prejudice denigrates the former characteristics as obstacles to be overcome, while it reifies the latter in ways that make them seem absolute and irresistible. In his paper, Stefano Oliverio traces this mal-contrivance to Descartes's construction of the scientific mind as different in kind from the mind of the child. He asserts that "the two main phenomena at the dawning of modernity - the invention of childhood and the birth of science-can be read as two sides of the same coin." Descartes's emphasis on mechanization and quantification in scientific method and understanding disregarded science's organic, qualitative, and desire-driven aspects, which became associated with immature thinking, that is, with that of women and children. More importantly, his ideal of rational thought-the cogito detached from its own physical embodiment and environment-condemned sensuality and instinct as necessarily irrational.

One consequence of this mal-contrivance is that "modern" education has aimed to move children away from their perceived irrationality, though as Athamatten explains, "[i]t takes Herculean effort for the child [in school] to stifle the instinct to reach in order to know, to extract itself from the continuous and coordinated flow that is 'life."' Another consequence is that adults, even professional thinkers-even philosophers-are not expected to beware of the ossification of habit which obstructs new values available in present experience and nurture our own childish intelligence that might have discerned them. Another consequence is that science-and all the disciplines modeled on science (including, somehow, philosophy) is constantly on guard against the kinds of irrationality just described, and this very guardedness, as Dewey recognized, alienates work from value, inquiry from experience, and the adults we have become from the children we still are. These consequences are mutually reinforcing. Thus, Dewey related the pseudo-problems that take up so much of the work of professional philosophers to the artificial problems that take up so much of the work of school children. Anthamatten describes this relationship as a "vicious cycle" in which professional philosophy and institutional education reinforce each other's anesthetic tendencies: "Whole schools of thought emerge and ossify around disembodied notions of being, knowing, and doing, creating paradigms and habitats that in turn reinforce these habits of disconnection and division."

As a "general theory of education," philosophy is meant to assist and direct the human search for meaning and value, both inside and outside the academy. But in order to serve this purpose, it must retreat from the historical mal-contrivance of human intelligence and personality and turn back toward childhood as a source of alterity that can interrupt, challenge, and potentially subvert the (after 
all) resistible, "adult" given. Also, for some of the authors here, philosophy is both a professional practice undertaken within academic communities of discourse and a way of life-a practical art of living. The latter understanding dates back to ancient western and Asian schools of thought and widens both the scope of philosophy-to include, for example, practices of diet, art, and civic engagement-and the scope of philosophers - to include anyone engaged in self-conscious, self- and social betterment (Hadot, 1995, 2002). The Philosopher as Child is a normative figure for both realms, signifying aspects of childhood that adults, having been educated and acculturated away from them, must find ways to reappropriate. The authors here focus on three of these aspects.

The first aspect of childhood is sensuality or corporeality. The Philosopher as Child takes her intelligence to be coextensive with her entire body, especially as it is only with and through the body that she encounters the world. The Cartesian ideal of the disembodied mind and the ancient religious and philosophical traditions that inspired it have always existed alongside art, literature, and philosophy that celebrates the body, not merely as an object and vehicle of sensual beauty and pleasure, but of intelligence and even wisdom. The latter has been a plank of the naturalism shared among pragmatists and humanists. Dewey frequently argued against the dualism of body and mind or soul. In an early essay, he wrote that, "The body, through the nervous system, is not only a physiological, but a psychophysiological organism" (1969, p. 104): "The psychical is homogeneously related to the physiological. . . . Now this gives us but one alternative: either there is absolutely no connection between the body and soul at any point whatever, or else the soul is, through the nerves, present to all the body. This means that the psychical is immanent in the physical. To deny this is to go back to the Cartesian position, and make a miracle of the whole matter" (p. 96). Dewey therefore saw children's corporeality - their unification of thinking and feeling, their acute sensitivity to physical sensation and the intensity of their interaction with the physical environment-as inseparable from their intelligence and their quickness to learn. As Anthamatten explains, "[i]t is the child that best epitomizes that the major organs of knowing are the hands and feet, and the process of learning and experiencing is better understood by the metaphor of touch and movement, than by sight and stasis. The mind is a hand, the hand is a mind." Dewey also practiced and advocated F. Matthias Alexander's technique for increasing somatic awareness and reeducating somatic habits of breathing, posture, and movement. In this way he modeled the philosopher's return to the body as both a site of intrinsic wellbeing and as a mechanism of intelligent inquiry and philosophical insight. The new discipline of somaesthetics advanced by Richard Shusterman $(1997,2000,2008)$ aims to facilitate this return by reconstructing philosophy as an embodied practice. As Anthamatten argues, "[p]erhaps the philosopher must create and maintain a certain theoretical distance from which to diagnose and understand the world. But the philosopher can never 'lose hold' of the world, nor let the world lose hold of him.' 
Another element of childhood recommended by our authors for philosophy is impulse, which connotes polymorphous desire, in opposition to the ancient and the modern Cartesian ideal of disinterested contemplation. David Kennedy refers us to one of Dewey's early works on education, School and Society (1900), in which he analyzed four kinds of human instinct or impulse. These forces, Kennedy argues, should be taken as rich resources for learning and growth in childhood: the social or communicative instinct, the impulse to make and create, the drive to investigate, and the expressive or artistic impulse. Following Dewey, Kennedy takes these impulses to be equally important for adult learning and growth. He traces their commendation by Dewey to the concept of "felt' reason" developed by Romantic theorists like Wordsworth, Rousseau, and Schiller, who contended that the rational is not opposed to, but rather continuous with, the sensual, and that impulses toward expression, creation, and play are as integral to human intelligence as are those toward form and order. Kennedy argues more generally that philosophyparticularly as a practice of direct, mutual encounter and shared wonderment with others in a discourse community-summons these childish impulses and brings them into artful interplay, for adults as well as for children.

These emphases on impulse and sensuality are, of course, central to the Peircean or Deweyan understanding of intelligence as the activity of a purposive organism inquiring, experimenting, collaborating, and otherwise working toward consummate experience in its current situation. It is only by going through that process that the organism becomes "educated," that is, better able to resolve problems and enjoy new values in future situations. Dewey famously criticized what he called the "spectator theory" of knowing as a kind of disinterested apprehension or seeing, and he offered instead an "agent theory" of knowing as know-how that results from the intelligent pursuit of ends-in-view: a combination of reflective thinking and firsthand experiencing (MW2, 9, 12; LW4). For Dewey, it was not only that embodied, interested engagement with the world is necessary for knowledge, but also that the value of knowledge is to facilitate that engagement. As David Granger puts it, "knowledge is largely subordinate to the direct qualitative meaning of things.... [I]ts value lies primarily outside of itself, in some external end. The intelligibility that it provides is meaning 'for' rather than meaning directly 'of'" (2006, p. 97). As Mark Dietrich Tschaepe's essay illustrates, this model of learning at once reinstates qualitative experience and subjective purpose as integral to scientific and philosophical method, and reinstates embodied, interested exploration as belonging to rationality. Further, as Oliverio claims, Dewey's reinterpretation of the meaning of childhood is nothing less than a revolutionary assault on the Cartesian foundation of modernity.

A third aspect of childhood recommended for philosophy is naivete, which connotes freshness of perspective, discernment of novelty, and playfulness. Dewey was acutely aware of the fact that new experience is always mediated by meanings gathered from past experience, by means of language and other cultural systems 
and by means of the deliberate manipulation of power interests: "[E]xperience is already overlaid and saturated with the products of the reflection of past generations and by-gone ages. It is filled with interpretations, classifications, due to sophisticated thought, which have become incorporated into what seems to be fresh naïve empirical material. . . . If we may for the moment call these materials prejudices ... then philosophy is the critique of prejudices" (LW1: 40). Dewey highlights the chronological aspect of this process of acculturation: the past reaches into and shapes the present and future. It is in this sense that childhood necessarily comes to represent innocence or naivete. Of course, the meanings developed in a culture and expressed in its literature, political institutions, methods of agriculture, kinds of art, and so on both enrich and constrain the values experienced by people within the culture by training their habits of perception, desire, and behavior in certain ways. The benefits of acculturation are the "funded experience of the past" (Dewey, 1967, p. 42), that is, the values worked out by past generations and made accessible in the present. The liabilities, on the other hand, are the alternative values that become opportunity costs, as well as the phenomenon of the dead metaphor Nietzsche described, where conventional norms no longer bring their associated values into experience (the rote prayer, the routinized flag salute, the all-too-familiar symphony).

Dewey stressed the need for individuals and societies to find ways to win some distance from their habits in order to reevaluate and, as necessary, reconstruct them. However, prejudices are, by definition, blind spots. To critique our own cultural or personal prejudices would require us to observe them from a perspective that does not incorporate them. Yet Dewey believed this was ultimately possible, if challenging: "We cannot permanently divest ourselves of the intellectual habits we take on and wear when we assimilate the culture of our own time and place... We cannot achieve recovery of primitive naïveté. But there is attainable a cultivated naïveté of eye, ear and thought, one that can be acquired only through the discipline of severe thought (Dewey 1967, p. 42). ${ }^{3}$ The "severe thought" Dewey discusses in this passage is the study of philosophy, broadly conceived, or rather, "the study, by means of philosophy, of life-experience" (p. 42). In fact, however, as Granger observes, this was not the only method Dewey offered for cultivating naïveté. Another was aesthetic experience, which, "by organizing experience around our perceptions of the qualitative uniqueness of some object or situation," reveals "a new dimension of the meaning of the human encounter with the world" (2006, p. 104).

A third way to cultivate spontaneity and freshness of perspective is described in detail in the articles in this issue. And while not found in Dewey, it seems an eminently Deweyan practice: dialogue with children. One important benefit for the philosopher who dialogues with children is epistemological. Insofar as philosophy involves constructing meaning from common and central human experience, and since so much of our experience is shared with the children in our lives, it would be irresponsible for us to inquire into the meaning of that experience without including their perspectives: the details they notice, the injustices they feel, the 
imaginative possibilities they see (Gregory, 2002). As David Kennedy has argued elsewhere, because "[p]hilosophy is the discipline that emerges most directly from the fundamental human sense of wonder, and which turns on questioning both reality and our knowledge of that reality," it therefore provides a unique opportunity to "[open] the experience of childhood to reflection, both on the part of children and of adults" (1998, p. 36).

Cultivated naïveté may also be described as an active sense of wonder, and adults who practice philosophy with children often find their own sense of wonder reawakening. This occurs not merely as intellectual curiosity, but rather as a more troubling sense of genuine doubt that signals a rupture in consciousness. This second benefit to the philosopher who dialogues with children is that it may enable her to "decenter from adultism" in a way that provides access to the child, that is, to "the unconscious, irrational, undersocialized other whom the adult carries within himself. The child is the adult's 'earlier self,' present in the latter both as a trace and a potential" (1998, pp. 32-33). ${ }^{5}$ The Philosopher as Child does not merely access or imitate the playful thought of children, but instead senses the child within her, and she practices philosophy as a meeting between these various elements of her intelligence. Anthamatten traces Dewey's "turn to the child as the model for praxis, possibility, and philosophy itself" to Nietzsche's parable of the child as "the highest metamorphosis of the development of the spirit." This metamorphosis or reconstruction is not, however, a retreat from adulthood, but an interaction, a dialogue, between the spontaneous and the stable, desire and detachment, feeling and semantic thought.

If Dewey had Romantic convictions that childhood offered an important model of the kinds of impulsivity, corporeality, and naïveté that adults must work to cultivate, the idea that adults might actually make themselves vulnerable to these shifts of consciousness by meeting children as equal partners in philosophical dialogue was beyond him. Nevertheless, Dewey saw philosophers, scientists, teachers, and school children, all, as agents of self-corrective growth, attempting to extract meaning from novel experience through intelligent thought, feeling, and action. In that regard, philosophers should know the serious playfulness that comes from direct engagement with the world. Children, for their part, should experience the exhilaration of having their immediate desires and concerns expanded and mediated by disciplinary knowledge and know-how. They should, that is, become philosophers.

\section{The Child as Philosopher}

Since Dewey's time the figure of the Child as Philosopher has been variously articulated and advocated in what has become the Philosophy for Children movement, ${ }^{6}$ for which Dewey is widely considered a seminal figure. The person regarded as the movement's founder, Matthew Lipman, decided to study philosophy while reading Dewey as a young army recruit in 1944. Lipman eventually wrote his disserta- 
tion at Columbia University as an extension of Dewey's aesthetics, ${ }^{7}$ which Dewey read and commended, and even began teaching at Columbia just a few years after Dewey's death. Lipman began work on his first philosophical novel for children in 1968 and left Columbia in 1972 to work on Philosophy for Children full-time at Montclair State College (now University), where he met and began a life-long partnership with philosopher of education Ann Margaret Sharp. Lipman and Sharp's was the first systematic approach to precollege philosophy education, including a theorized curriculum and pedagogy, but other materials and approaches have since been developed in many parts of the world. Today, the International Council for Philosophical Inquiry with Children has members in over 60 countries. ${ }^{8}$ Lipman and Sharp's program is the focus of most of the papers in this issue, and, importantly, most of these authors have engaged children philosophically.

Much has been made of the influence of Dewey and other pragmatists on Philosophy for Children (Bleazby, 2011; Gregory, 2000; Johnson, 1995; Cam, 1994; Melville, 1990), something Lipman and Sharp both acknowledged and qualified (Lipman, 1994; Lipman and Sharp, 1978; Sharp, 1996, 1995a, 1995b, 1993). The fact remains, however, that Dewey himself did not describe children as philosophers and did not recommend philosophy as a subject for precollege education. In fact, though he wrote in broad terms about teaching for reflective thinking (1998), as Martha Nussbaum recently noted, Dewey "never addressed systematically the question of how Socratic critical reasoning might be taught to children of various ages" (2010, p. 73). Nussbaum sees Lipman's work as continuous with Dewey's philosophy of education and thinking about democracy, but as the essays in this volume amply demonstrate, the relationship of Dewey's thought to children's philosophical practice is a complicated one. While many of the aims, methods, and materials that support that practice are consonant with some of Dewey's most important and well-known writing on childhood, philosophy, and education, some are just as clearly instances of departure, or at least of "Deweyan way[s] of going beyond Dewey" (Striano, 2002, p. 63).

Apart from the biographical considerations just mentioned, the major ways in which Dewey has informed the Philosophy for Children movement may be summarized in terms of three much-debated issues at the heart of that movement: whether children can practice philosophy, whether (and why) they should be invited and guided to do so, and, assuming positive responses to the first two, how this should happen. Theorists in the movement have found important resources for addressing each of these issues in Dewey's work.

\section{Can Children Practice Philosophy?}

Dewey's account of intelligence as the ability of an organism to pursue ends-inview by changing the ways it interacts with its environment means that very young children-even infants and babies - already partake in intelligence. As he explains, "[T] endencies toward a reflective and truly logical activity are native to the mind, 
and ... show themselves at and early period, since they are demanded by outer conditions and stimulated by native curiosity. There is an innate disposition to draw inferences, and an inherent desire to experiment and test... . A baby, even at a comparatively early period, makes inferences in the way of expectations from what is observed" (1998, p. 83). In his contribution to this volume, Anthamatten draws our attention to one of Dewey's earliest and most influential essays, "The Reflex Arc Concept in Psychology" (1896), in which he argued that the only way to explain learning from experience is to assume that the child having the experience is already an intelligent being pursuing value in its environment. The reaching of the child's hand for the candle flame is not, to begin with, an arbitrary act which then becomes conditioned by the pain of the flame. Rather, it is an intelligent, purposive act, which already involves the apprehension of certain meaning and value. The learning that occurs is the expansion of a former meaning and value of candle (beautiful light) to include a new one (pain). Thus, for Dewey, the child's mind is neither a blank slate nor an engine of blind driving toward sensation. It is instead a circuit of purposeful, intelligent interaction with the world. Tschaepe relates this to children's proto-scientific enthusiasm for exploring their physical environment and "formulating their own explanations, as scientists do, based upon observation and rudimentary experiment."

In addition to his early work in psychology, Dewey's philosophy of education drew on his later work in social psychology. Dewey followed his Chicago colleague George Herbert Mead (1934) in emphasizing the importance of the learner's interaction with her social environment, which enables her to internalize the discursive thinking that takes place between herself and others. As Nadia Kennedy notes in this issue, Lipman drew parallels between twentieth-century Soviet psychologyespecially Vygotsky and Davydov—and the pragmatist social psychology of Mead, Dewey, and Buchler. ${ }^{9}$ His conception of the classroom "community of philosophical inquiry" as a pedagogy of "cognitive cooperation with ... peers and mentors" (1996, p. 45) is recognized as a ground-breaking application of social learning theory in education (Lim, 2004; Margolis, 1996). This theory has been used in Philosophy for Children in support of the claim that young children, by virtue of their participation in ordinary language communities, are already practiced in a host of complex cognitive operations, including abstract conceptualization, agreeing and disagreeing, asking for and providing reasons, offering explanations, giving examples and counterexamples, classifying, making distinctions and connections, reasoning by analogy, reasoning syllogistically, entertaining different perspectives, and self-correcting (Kennedy, 1994). Importantly, this means that "the moves of the language game of philosophy ... are implicit in the semantic and syntactical structures of language, and therefore always implicit among those who use language. If this is the case, then to the extent that children share a linguistic universe with adults, they share the capacity for at least some of the critical moves of philosophical dialogue, on some level" (Kennedy, 1999, pp. 350-351). Children's philosophical capacity is 
not only a matter of their cognitive ability, but also of their propensity for curiosity and wonder. Children, on the whole, seem more susceptible than most adults to genuine philosophical wonder, and in this issue Jennifer Bleazby attributes this in part to the strong imaginative capacities characteristic of childhood. Bleazby constructs a Deweyan account of the "intelligent imagination" and relates it to the way children "wonder about the seemingly mundane, ask questions of a philosophical nature, and are constantly searching for meaningfulness." In accounting for children's imaginative propensities, Bleazby also indicates the chronological aspect of acculturation: that children encounter so many novel experiences before, and as they form, the schemata of concepts, and that, for the younger, "[t]heir thinking has ... not been so moulded by dominant cultural beliefs and values."

Dewey is generally read, then, as supporting claims that young children are capable of wondering and looking for meaning, of thinking abstractly and logically, of conversing with others sympathetically, and of adjusting their own thinking and acting in accordance with what they learn by doing so-and that they do these things in some sense paradigmatically. The question remains, however, whether children can wonder, think, imagine, and inquire philosophically — that is, about philosophy. This is the question for which there is the least direct support in Dewey's work; and yet, an argument can be made in support of a positive answer to this question by drawing on the way Dewey sometimes characterized the work of philosophy and the nature of philosophical judgment. One of Dewey's most important insights was that philosophy addresses some of the meaning of our everyday, ordinary experiences. Dewey understood "ethical," "aesthetic," "political," and other philosophical categories to refer to dimensions of ordinary human experience, rather than remote intellectual or esoteric concerns segregated from it. In one of his best-known books, Art as Experience (1934), he argued that our experiences with the fine arts are merely instances of the kinds of aesthetic meaning that are available in all experience, that is, if we are awake to it. ${ }^{10}$ Also, as we become awake to the aesthetic dimension of our experience, we find not fixed aesthetic qualities, but rather aesthetic problems and possibilities unique to each situation. Moreover, the ways we respond to these problems and possibilities will help determine the aesthetic outcome: whether those situations become more or less beautiful, interesting, and emotionally connected to other situations. In this way, the study and practice of philosophy can help us to wake up to the ethical dimensions of our experience, the political, the logical, even the metaphysical, and help us to find ways of thinking, feeling and acting that make our experience more loving, more just, more reasonable, and so on. ${ }^{11}$

The only remaining question, then, is: does the ordinary experience of children have these dimensions? Dewey did not address this question directly, though some of his writing on moral and aesthetic education assumes a positive answer. The pioneers of Philosophy for Children-Matthew Lipman, Ann Margaret Sharp, and Garreth Matthews (all of whom died within the last two years) - have demonstrated incontrovertibly that children's experience is just as replete with philo- 
sophical meaning as is that of adults (Lipman, 2003; Matthews, 1996, 1980; Sharp, 2004). Children delight in the beauty and horror of the insect world. They express outrage at perceived playground injustices. They are fascinated by death and puzzle over cosmogony and theology. They are self-conscious about their own propensities for compassion and cruelty. Moreover, they are full of questions about all of these aspects of their experience and eager to discuss them, to hear and make up stories about them, and otherwise think through them. Children are eager not only to make sense of their experience, but also to make their experience more meaningful, in part by opening up its philosophical meaning. This makes them philosophers in the truest sense.

\section{Should Children Practice Philosophy?}

Dewey has been a major resource for those arguing that children not only can, but should, practice philosophy. Perhaps the reason given most often in support of this position is that practicing philosophy is an effective method of learning to think well, which Dewey urged as among the most important aims of education (1998). A leading figure in the critical thinking movement, Lipman repeatedly recommended philosophy as the most likely means of reaching this aim, as "the discipline par excellence for making sense of things and for preparing students to think in the more specific disciplines" (1996, p. xv). Proponents of Philosophy for Children have argued that practicing philosophy helps students learn to think well in a number of ways, such as making sound inferences and other reasoning moves (Cannon and Weinstein, 1985; Gratton, 2000; Lipman, 1984; Weinstein, 1988), as well as constructing and critiquing logical arguments (Slade, 1989; Splitter, 1988). More broadly, it has been argued that philosophy teaches children the nature of inquiry as an open-ended, self-corrective search for reasonable belief and value (Fisher, 2008; Lipman, 1991; Splitter and Sharp, 1995), along with strategies for inquiry such as identifying problems, formulating inquiry questions, constructing and testing original hypotheses, and finding and analyzing relevant data (Dalin, 1983; Haynes and Haynes, 2000; Matsuoka, 2004). In addition, in this issue Tschaepe demonstrates how Dewey's conception of scientific explanation "should be utilized as a self-empowering philosophical tool within the context of science education." In all of these ways, philosophical inquiry presents a stark alternative to traditional pedagogy, which "presents students with facts as if they are settled, unproblematic and ready to be memorized," and which stresses "efficiency and accountability through government-mandated curriculums; the rigid alignment of stated learning outcomes with curriculum content, pedagogy and assessment, and usually involves high-stakes testing" (Bleazby).

As Bleazby explains here, however, reflective thinking is not reducible to logical operations, but, just as importantly, involves the imagination. And "[w]hile children may have a natural propensity for imaginativeness, their thinking may also be more fanciful than imaginative at times ... [and] need to be scaffolded." Bleazby's 
essay draws broadly from Dewey's work to helpfully distinguish six different roles he gave to imagination within the method of intelligence. These include conceiving alternative ends-in-view for problematic situations, suggesting means to reach them, evaluating means in terms of possible consequences, drawing on relevant past experience, making diverse perspectives accessible, and enabling social interaction. Given this centrality of imagination to reflective thought, Bleazby argues that rather than help students to "overcome or control their imaginations," as Plato advised, "all schooling must cultivate the imagination as a basic, interdisciplinary capability." Bleazby's thesis that Philosophy for Children is a likely method for fostering children's "intelligent imagination" points to specific ways in which that program structures the work of philosophy: that it "involves questioning, wondering, criticizing and going beneath the surface of what is immediately given," that it generates answers "which are likely to be contentious, open to criticism and lead to further questions," that it relies heavily upon imaginative devices such as allegories, analogies, and thought experiments, encourages the consideration of alternative perspectives, and utilizes "the corrective potential of others [to] avoid thinking that is unrealistic and fanciful as opposed to imaginative."

A second reason that children ought to be invited and guided to practice philosophy is that, like all humans, they are "meaning-seeking creatures" (Armstrong, p. 2). As we observed above, the inexperience of younger children prompts them to wonder at every aspect of experience. Their love of stories indicates their strong urge to make meaning in experience, and the imaginative, off-kilter meanings they often make are an important reminder of the contingent nature of the adult meanings they are expected to appropriate. For adolescents, philosophical wonder is of a different kind. For one thing, they struggle with a problem contrary to that of young children: the varied and complex academic and cultural knowledge they have accumulated can be confusing and overwhelming, giving rise to questions about how it all fits together and what it all means (Suissa, 2008). And as adolescents approach decisions about careers, sexuality, and political engagement, existential questions about the meaning and purpose of their own lives become acute. As Jacob Needleman has observed, these are the kinds of questions that "are educated out of us by the time we reach so-called maturity" (1982, p. 85). Needleman, who created a high school philosophy program in the late 1970s, wrote of his students, "I wanted them to feel permitted to ask great questions...to feel the natural right to ask of the universe those simple, gut-level questions that are strongest in childhood, or which appear in moments of great disappointment or tragedy" (p. 85).

In his essay, David Kennedy argues that young people's philosophical questioning is intensified today, especially for those who consume vast amounts of commercial media, as they imbibe the restlessness and value-uncertainty that characterizes our postmodern cultural moment: "[W]e live in a historical era in which philosophical questions tend to become more and more visible as cultures and ideologies become increasingly inter-visible, and absolutisms of all kinds less 
and less epistemologically viable [and] these doubts and questions are ... communicated, directly or otherwise, to children from an early age and in a multitude of ways." This scenario brings into sharp relief Bleazby's argument that the capacity for independent thinking and personal autonomy-especially the use of intelligent imagination to envision ethical and political conditions alternative to the status quo and to the thoughts of powerful others-is particularly important "for marginalized groups, including children and young people [whose] interests and experiences may be those least reflected in dominant values and knowledge." She further asserts that the philosophical concepts around which children's inquiry typically centers-for example, truth, fairness, time, beauty, person- “are so fundamental to all our experiences and understandings, philosophical inquiry can provoke us to imaginatively reflect on every aspect of our lives."

The primary value of philosophy, for children as for adults, is not that it makes us smarter or more successful. Rather, it offers us a method of inquiry and a history of ideas that can help us in our struggle to make sense of academic knowledge, of the world of our immediate and our mediated experience, and of our place in it. This use of philosophy is consistent with Dewey's "Pedagogical Creed," which stresses that "education . . is a process of living and not a preparation for future living" (1897). It points to the intimate connection Dewey saw between philosophy and education, which, as Oliverio reminds us, he traced to the "Socratic turn" of philosophy in ancient Athens. Dewey strongly identified with Socrates's belief that the purpose of philosophy is not to win arguments but to improve life; and Dewey often described philosophy in this expansive sense, the sense in which it is co-extensive with education: "[P]hilosophy is love of wisdom; wisdom being not knowledge but knowledge-plus; knowledge turned to account in the instruction and guidance it may convey in piloting life through the storms and the shoals that beset life-experience as well as into such havens of consummatory experience as enrich our human life from time to time" (2008c, p. 389).

\section{How Should Children Practice Philosophy?}

Since Lipman and Sharp began their work on Philosophy for Children in the early 1970s, many approaches to that work have been developed, both in and out of sync with their own. The authors in this issue of Education and Culture focus on two major elements of the Lipman and Sharp program-its method and its contentalong with ways of applying both across the curriculum.

By far the most innovative aspect of the Lipman and Sharp program, and the most widely discussed in the research literature and in this volume, is the community of philosophical inquiry (CPI; Lipman, et al., 1980). In this practice, students share a stimulus which provokes philosophical questions-such as a passage from one of Lipman's philosophical novels-and construct an agenda for discussion out of questions they raise about the experience, depending on what they found most interesting or puzzling. They pursue these questions with each other in a dialogical 
inquiry facilitated by a philosopher with pedagogical preparation or a teacher with philosophical preparation. In these dialogues, students explore their questions from many perspectives, consider and evaluate possible answers, and attempt to hone in on the most reasonable positions, while at the same time expanding their understanding of the topics' complexities. David Kennedy describes the process this way: "In CPI each individual, thinking for herself and with others, becomes a practicing philosopher, and the group-as-a-whole shifts and self-corrects and develops as a philosophical and an ethical culture through the reconstruction and coordination of each individual's philosophical beliefs." This description is linked thematically to Bleazby's explanation as to why empathetic imagination that entertains and creatively integrates diverse perspectives is necessary for all inquiry, all dialogue and all human community. Indeed, the most important pedagogical innovation of CPI is the way it implements social learning theory. As Nadia Kennedy puts it in her paper, students in a CPI cultivate "individual dispositions and reflective habits that are internalizations of procedures that originate in the community." She argues that this process exemplifies what Dewey meant by an "educative experience," because "[ $\mathrm{t}$ ] he reconstruction of habit that ensues is marked by a broadened perspective, a shift of attitude, an increase in knowledge-in short, in enduring changes of a psychological nature that follow from the acquisition of new meanings."

As many Philosophy for Children theorists have noted and as David Kennedy notes here, "the logic of CPI is Deweyan and Pragmatic, for it is based on problematization in the interest of the enhancement of a lived situation." This is significant for two reasons. First, it means that CPI teaches students a Deweyan "logic of inquiry," where knowledge is seen as a new understanding or way of doing something that results from an effort of collaborative thinking and experimentation, and by a group of people who share an interest in the outcome. As Nadia Kennedy explains, "Lipman took from Dewey the notion that inquiry should begin with an experience ... that can prompt students to encounter uncertainty and perplexity, and that motivates them to inquire into the problematic of a situation and to search for its resolution." She goes on to say that Lipman shared Dewey's aim of inquiry-based education, but saw "philosophical inquiry as a more promising way to achieve an inquiry-based educational model than the scientific method." Tschaepe, however, maintains that science education could become inquiry based if students learned to practice Dewey's method of scientific explanation, thus becoming "philosopherscientists."

Second, CPI follows not only Dewey's logic of inquiry but also his phenomenology of inquiry, according to which (following Peirce) inquiry must begin with a problem, question, or doubt and must aim at a solution or resolution, both of which are genuinely felt-something in which the inquirer actually has a stake. This was also the basis of Dewey's philosophy of education: children are continually challenged and provoked by natural and cultural phenomena that present new obstacles to the kinds of experiences they value, or present possibilities for novel kinds of 
value. In such cases they must experiment with new ways of thinking, feeling, and acting to discover how to solve the problem or realize the new value quality. School curricula should help them to deal with opportunities for meaning-making in their current lives, not set up an artificial realm of scholastic experience segregated from the rest of life. The pedagogical justification for CPI is partly that it enables students to apply reflective thinking and interperspectival dialogue to situations in their own experience that have latent aesthetic, ethical, or other kinds of philosophical meaning, and to see what can be made of them.

The CPI has also been recommended as a pedagogy for democratic citizenship, drawing on Dewey's conception of social democracy as a community that employs the cooperative intelligence of its members to formulate and pursue its purposes-its collective ends-in-view (Gregory, 2005). Theorists inside and outside the Philosophy for Children movement have asserted that public education should initiate the young into the culture of collaborative deliberation we wish to foster and fortify (Nussbaum, 2010; Gutman, 1987); and Lipman saw "[c]ommunities of deliberative inquiry [as] microcosms of democracy not simply because they are selfgoverning groups but because their modes of self-regulation and self-correcting can be carried over from the smaller groups to the more massive societies" (1998, p. 25). David Kennedy explains that some kind of CPI is necessary to all democratic practice not merely because of how it operationalizes critical thinking and the drawing out of diverse views on topics important to the group, as well as power sharing in management of the discourse, but also because it invokes parrhesia or frank truth telling as its primary mode of discourse. This introduces "negativity, interruption, problematization, interrogation, reinvention, self-correction, epistemological and moral suspense" as elements necessary for genuine inquiry into real controversies in any actual human community.

In his article, David Kennedy points to another use of CPI that is a Deweyan and a Lipmanian way of going beyond both: as a mechanism not only for democratic meaning making, but for problem solving, power sharing and self-governance in schools. Kennedy sees Lipman's CPI as “not just a pedagogical device, but the projection of an ideal speech community dedicated to a normative form of democratic practice." Inevitably, some of the philosophical questions school children raise for discussion will be about their own political and ethical relationships-to one another, to adults, and to the school and other institutions in which they participate. And as Bleazby observes, philosophy provokes and scaffolds students' imagining alternatives to the status quo. In these ways the practice of CPI cultivates students' political awareness; but Kennedy advocates it further as way of negotiating their needs and interests with those of the adults in their school settings. As he argues:

[B]ecause it is by definition a space of dialogue and interrogation, CIP introduces both an element of interruption and even of implicit social danger into the adult-child collective we call school, which traditionally assumes the absolute epistemological authority of the adult. But it also introduces 
a concrete, workable discourse model for negotiating that danger in the form of ongoing philosophical and social reconstruction, which includes the reconstruction of the adult-child relation.

To the extent that CPI-especially in its political and moral aspects-brings children and adults together in inquiry-driven discourse and power sharing that changes the terms of the adult-child relationship beyond the discourse episodes, it is a radical practice without direct support in Dewey.

The second major element of Philosophy for Children examined in this issue is the way it makes philosophy - as a range of certain kinds of questions and a repertoire of positions and systems of thought constructed in response to them-available for the consideration of young people. Again, this was not something Dewey envisioned, but it was undertaken under his influence. Lipman said of Dewey that "implicit in his writings are pedagogical guidelines which would be applicable to any curriculum, even to those that had not yet been invented, like educational philosophy (i.e., philosophy functioning educationally, like Philosophy for Children)" (1994, p. 148). One of those guidelines was that "[a]nything which can be called a study, whether arithmetic, history, geography, or one of the natural sciences, must be derived from materials which at the outset fall within the scope of ordinary life-experience" (Dewey, 1967, p. 73). This gives educators the responsibility for "determining the range of [students'] past experience [and] finding activities that connect in vital ways with it" (p. 75). A second guideline is that "growth depends upon the presence of difficulty to be overcome by the exercise of intelligence" (p. 79). This means that the curricula must highlight problems within the range of the students' experience meaningful enough and challenging enough "that it arouses in the learner an active quest for information and for production of new ideas" (p. 79).

Lipman's original educational innovation was to conceive of the philosophical novel for children, one aspect of which would be to reconstruct the history of philosophy to be both accessible and relevant to children of various ages. Here, for example, is Lipman's translation of Descartes's First Meditation:

Today Seth said, "Elfie hardly ever talks. Maybe she’s not for real!"

That just shows how wrong he can be! Maybe I don't talk much, but I think all the time. I even think when I sleep. I don't have fancy dreams. I just think, when I'm asleep, about the same things I think about when I'm awake.

Last night I woke up in the middle of the night and I said to myself, "Elfie, are you asleep?" I touched my eyes, and they were open, so I said, "No, I'm not asleep." But that could be wrong. Maybe a person could sleep with her eyes open.

Then I said to myself, "At this moment, am I thinking? I really wonder.”

And I answered myself, "Dummy! If you can wonder, you must be thinking! And if you're thinking then, no matter what Seth says, you're for real." (Lipman, 2004, pp. 4-5) 
Oliverio calls this Lipman's "reterritorializing" of the history of philosophy into childhood experience, and offers in his paper this summary of the Deweyan pedagogy in Lipman's fiction:

[I]n writing his stories Lipman moves from some ideas (e.g., beauty, justice) and from the treatment they received in the philosophical tradition; he then identifies experiential situations-suitable for children-in which those ideas can operate as possible tools to reconstruct and reorganize experience in order to add to meaning; finally, he embodies the different epistemic options (corresponding to different philosophical traditions) in different characters, who are engaged in a common inquiry, homologous to and modeling the inquiry which will take place in the classroom community of inquiry.

Lipman's use of narrative rather than exposition enacted his own theory of the narrative structure of philosophical thinking (the drama of encountering and coping with perplexity) and of the philosophical text as one that provokes perplexity in the reader and invites her into an active, dialogical relationship with it-one that is not merely informative but also transformative of the reader's thinking (De Marzio, 2011). And Bleazby argues that narrative is particularly effective for engaging children's imaginative thinking in philosophical inquiry, including hypothetical and metaphorical thinking, and for creating further fictional scenarios. Oliverio draws on the work of Ann Sharp and Ronald Reed to explain how Lipman's narrative "translation" of the history of philosophy "makes it effective for the reorganization of children's experience [; and] broadens children's ability to have meaningful experiences." Likewise, David Kennedy argues that Lipman's philosophical novels answer Dewey's called to close the gap between the psychological and the logical, the child and the curriculum, both by illuminating philosophical puzzles in children's own experience and by "arous[ing] her innate logical dispositions." Also, as Nadia Kennedy points out, "[t]he agenda of the Lipmanian group discussion" around philosophical material in the novels "is guided by students' interests, not by the logical organization of the subject matter."

A third way of inviting children to practice philosophy discussed herein is engagement with philosophical content and method in traditional school subjects. As David Kennedy explains, "all school curriculum-each of the disciplines-has a philosophical dimension, and ... this dimension is the very one that makes it most meaningful." Nadia Kennedy argues, moreover, that "Lipman's Philosophy for Children program [can be] seen as a framework for the design and performance of philosophical inquiry in all disciplines-something that he himself contemplated but never realized." Her essay thus delineates specific ways in which philosophy can be brought into "a situation of encounter" with mathematics, an encounter that might provide a model for doing so across the disciplines: "[discipline-based] concept work; philosophical inquiry into the common, central and contestable concepts that are common to the disciplines; aesthetic inquiry ... inquiry into the 
benefits and the limitations of the [disciplinary] instrumentarium; ethical inquiry into the [cultural] uses of [the discipline]; and epistemological inquiry aimed at the reconstruction of mental beliefs or habits."

Nadia Kennedy's and Tschaepe's essays demonstrate how engaging students in inquiry regarding the philosophy of a discipline at once helps them to appreciate the discipline's intriguing philosophical dimensions and its relationship to other disciplines, as well as to better recognize the disciplinary dimensions of their own experiences. Doing so, Kennedy points out, avoids the miseducative ways in which subjects are typically taught: "ignoring students' interests, a pedagogy based on routine, the dominance of trivial activities and tasks, [and] the increasing disconnection of the subject matter from students' everyday knowledge and experience." Tschaepe argues similarly that a philosophical approach to science education would help to deflate the authoritarian character of typical science education. What is more, Kennedy argues that when philosophy is brought into dialogue with other disciplines, "each type of inquiry can add an extra depth to the other, and help us increase our awareness of what each can and cannot accomplish." This pedagogical function of philosophy is also noted by Bleazby, who explains that philosophy uniquely "draws out the problematic, contentious, and thus imaginative, aspects of other disciplines. Other school subjects often take it for granted that truth, freewill, justice, democracy and beauty exist, and they even make uncritical assumptions about what such concepts mean. In contrast, philosophy assumes that such concepts are contentious, and much philosophical inquiry is devoted to exploring and defining them."

\section{Dewey on Philosophy and Childhood}

The fact remains, however, that Dewey himself did not describe children as philosophers and did not recommend philosophy as a subject of precollege education. As Oliverio sees it, Dewey seemed not to appreciate "the wealth of educational opportunities embedded within the philosophical tradition," or what Lipman termed "educational philosophy." This supports David Kennedy's claim that the two dimensions of Lipman's program - “introducing philosophy as a subject matter in the elementary school through a series of philosophical novels written for children" and the "guided, structured, dialogical speech community . . called 'community of philosophical inquiry"”-were both "inaugural educational ideas." Kennedy observes, further, that neither of these ideas occurred in the history of nineteenth- and twentieth-century libertarian, anarchist, or socialist educational praxis.

The influence of Dewey on Philosophy for Children and the Deweyan character of its methods and materials have led many to wonder why Dewey himself did not inaugurate such a movement. Lipman actually addressed this question and he offered two answers. The first had to do with the nature of philosophy of education in Dewey's time. Dewey's primary educational interest was to introduce inquiry into schools, but philosophers, unlike scientists, had no interest in becoming involved with schools: 
There was no way [Dewey] could imagine the philosophers of education with whom he was familiar engaging in the experimentation and the organization of nuts and bolts observations that he deemed essential to the future of education. He was thoroughly familiar with the philosophers of education of his day, and he could see that they had relatively little interest in establishing a reciprocal theory/practice relationship with the schools. Their great love was philosophy in the abstract, as it dealt with highly theoretical themes relating to education.... No, the philosophers of education, Dewey must have concluded, neither would nor could involve their beautiful discipline in the noisy turmoil of the schools. The science educators, on the other hand, he must have thought, knew exactly what was needed. (Lipman, 1994, pp. 147-148)

Perhaps Dewey meant something like this when he wrote that "the reconstruction of philosophy, of education, and of social ideals and methods thus go hand in hand" (MW9: 341). In any case, and whether or not Lipman's supposition is correct, Dewey's critique of the aloofness of professional philosophers is well-known.

Second, Dewey's famous phrase that philosophy could be understood as the general theory of education, meant, for Lipman, that philosophy was a theoretical discipline, one without a direct empirical, experimental practice. This tension in Dewey is something Lipman noticed as an undergraduate and never resolved. Toward the end of his life, he wrote,

Dewey minced no words, when he said that philosophy would be "the general theory of education." He meant that it was to be the exception to the rule. In every other discipline there had to be an interpenetration of theory and practice, but in the case of philosophy, not so. ... Nowhere in his writings does he refer to the practical use of philosophy in education. It was for him, I believe, unthinkable. (1994, p. 148)

This second reason is echoed by Oliverio, who explains Dewey's passing over the possibility of educational philosophy by looking at the tasks Dewey set for the profession, one of which was to be a meta-level inquiry that mediates and critiques other fields of inquiry - tracing their remote origins and consequences-but is removed from the on-the-ground problem solving of each.

A third reason offered by Oliverio is that the principal task Dewey set for philosophy-cultural criticism-requires a range of cultural understanding and experience that is beyond the experience of children. Thus, Dewey suggested that "From one point of view ... the chief role of philosophy is to bring to consciousness, in an intellectualized form, or in the form of problems, the most important shocks and inherent troubles of complex and changing societies since these have to do with conflicts of value" (2008c, p. 30). James Campbell (1995) has consequently described "Dewey's understanding of the cultural role of philosophical inquiry" as "a persistent attempt to uncover and evaluate, and replace if necessary the basic assumptions of culture" (p. 93). If, for Dewey, it was the philosopher's task, for example, to critique 
the way class prejudice distorted aesthetic experience and to recommend paying attention to the potential aesthetic meaning of ordinary experience, he would not, it seems, have taken the ordinary citizen who did so to be practicing philosophy. Oliverio characterizes Dewey's view of philosophy as essentially Hegelian in that the meaning and value of historical philosophical positions and systems of thought is their continual reappropriation by contemporary philosophers who can connect them to the "constantly new emergences of culture" - again, a work of great sophistication beyond the ken of children.

Part of Dewey's "Pedagogical Creed" (1897) was that "[e]xisting life is so complex that the child cannot be brought into contact with it without either confusion or distraction." If, as Dewey suggested, cultural critique requires the cultivation of naivete vis-à-vis one's own cultural assumptions, it would seem, on the other hand, that it also requires sufficient enculturation to understand what one is critiquing and why. In this vein, Richard Rorty has argued that "[p]rimary and secondary education will always be a matter of familiarizing the young with what their elders take to be true, whether it is true or not. It is not, and never will be, the function of lower-level education to challenge the prevailing consensus about what is true. Socialization has to come before individuation, and education for freedom cannot begin before some constraints have been imposed" (p. 118).

David Kennedy situates Dewey within the broad historical movement that includes libertarian, anarchist, and progressive educational theorists, many of whom favored the notion of "integrated education" developed by Marx and Kropotkin. It emphasized children's involvement in "interest-driven, hands-on experience associated with home industries and arts and crafts" which, it was believed, would "counterbalance the abstract work that was identified as a major source of the dramatic irrelevance of the traditional school to children." Kennedy then quotes Dewey on the necessity for such "childish inquiry": "The child has not much instinct for abstract inquiry.” In contrast, Nadia Kennedy notes that “[p]hilosophical inquiry in Lipman's usage is an encompassing term that signifies work related to reasoning and making judgments, conceptual analysis, and engagement in interpersonal communication and deliberation." Perhaps it is fair to say that Lipman and Dewey both saw philosophy as the discipline in which the "method of intelligence" was applied to "problems of men [sic]." But, for Dewey, that primarily meant addressing large-scale ethical, political, and cultural issues, while for Lipman it also meant addressing issues in personal experience and in a way that was within the ken of even young children.

Making matters even more complicated, one of Dewey's central educational principles was that " $[\mathrm{t}]$ he only way in which a person can reach ability to make accurate definitions, penetrating classifications, and comprehensive generalizations is by thinking alertly and carefully on his own present level" (1998, p. 84). It follows from this that if the most important function of philosophy is cultural criticism, the only way young people can reach the ability to utilize that function on a national and global scale is to practice it on the scale of their own social milieu: the family, 
the school, the neighborhood, and the vast world of media they inhabit. And to do this they must begin to take notice of the political, ethical, aesthetic dimensions of these domains, to notice problems and opportunities and to pursue experiences that seem worth having. They must "practice democracy" (Gregory, 2005), in Dewey's novel articulation, as a mode of collective doubt-inquiry-growth within their own social sphere. In fact, Dewey recommended something close to this when he stated that "[f]ull education comes only when there is a responsible share on the part of each person, in proportion to capacity, in shaping the aims and policies of the social groups to which he belongs" (MW12: 199).

Theorists in Philosophy for Children have, in fact, addressed the phenomenon of "The Child as [Social] Critic" (Sharp, 2009). It seems to fit squarely within Dewey's vision of the school as a "form of community life" that continues the meanings and activities of the home life while reproducing, in a simplified form, the larger social life so that children's "social consciousness" is expanded, and of the school as a site of meeting and mediation of various other social institutions. In this regard, he wrote, "It is idle to expect the schools to send out young men and women who will stand actively and aggressively for the cause of free intelligence in meeting social problems and attaining the goal of freedom unless the spirit of free intelligence pervades the organization, administration, studies, and methods of the school itself" (LW11: 254).

Anthematten remarks on this notion that, "The child reminds us of that 'full presence' from whence we began, and demands an education, a politics, and a philosophy that deepens that presence." To invite children to practice philosophy as ethical, aesthetic, political, and cultural criticism is, as David Kennedy argues, not only to change the nature of adult-child discourse within schools. It is also to change what counts as epistemological and authoritative privilege in the adultchild relationship, and in fact to change the school into a "miniature society of [an] adult-child collective." Yet this is necessary for the emergence of both the Child as Philosopher and the Philosopher as Child. The two are mutually dependent in that their growth depends on their encounter in mutual practice. The possibility of that encounter is perhaps the most significant reconstructive possibility to emerge from the mutual encounter of the disciplines of education and philosophy that occupied so much of Dewey's thought.

\section{References}

Armstrong, K. (2005). A Short History of Myth. New York: Knopf.

Bleazby, J. (2011). “Overcoming Relativism and Absolutism: Dewey's Ideals of Truth and Meaning in Philosophy for Children." Educational Philosophy and Theory 43(5), 453-466.

Cam, Philip (1994). "Dewey, Lipman, and the Tradition of Reflective Education," in Taylor, M., Schrier, H. and Ghiraldelli, Jr., P. (Eds.), Pragmatism, Education and Children, (pp. 163-181). Amsterdam: Editions Rodopi B.V. 
Campbell, J. (1995). Understanding John Dewey. Chicago: Open Court.

Cannon, D. and Weinstein, M. (1985). “Reasoning Skills: An Overview." Thinking: The Journal of Philosophy for Children, 6(1), 25-26.

Dalin, G. D. (1983). "Critical Thinking and Problem Solving in the Elementary School Curriculum.” Analytic Teaching, 4(1), 23-24.

De Marzio, D. M. (2011). "What Happens in Philosophical Texts: Matthew Lipman's Theory and Practice of the Philosophical Text as Model." Childhood \& Philosophy, 7(13), retrieved September 5, 2012, from http://www.periodicos. proped.pro.br/index.php?journal $=$ childhood $\&$ page $=$ article $\&$ op $=$ view $\&$ pa th[] $=855$.

Dewey, J. (1897). “My Pedagogical Creed." School Journal, 54, 77-80, retrieved September 5, 2012, from http://dewey.pragmatism.org/creed.htm.

-_- (1985). The Middle Works of John Dewey, Volume 9, 1899-1924: Democracy and Education, 1916. (Jo Ann Boydston, Ed.) Carbondale: Southern Illinois University Press. (Original work published 1916).

-_- . (1967). Experience in Education. New York, Collier Books. (Original work published 1938).

_-_- (1969). "Soul and Body," in The Early Works of John Dewey, Volume 1, 1882 1898: Early Essays and Leibniz's New Essays (pp. 93-115). (Jo Ann Boydston, Ed.). Carbondale: Southern Illinois University Press. (Original work published 1886). _-_. (1986) Logic: The Theory of Inquiry (LW12). Carbondale, IL: University of Illinois Press. (Original work published 1938).

- - . (1998). How We Think: A Restatement of the Relation of Reflective Thinking to the Educative Process. New York: Houghton Mifflin. (Original work published 1933).

_-_. (2008). The Later Works of John Dewey, Volume 1, 1925 - 1953: 1925, Experience and Nature. (Jo Ann Boydston, Ed.). Carbondale: Southern Illinois University Press. (Original work published 1925).

_-_- (2008b). The Later Works of John Dewey, Volume 8, 1925 - 1953: 1933, Essays and How We Think. Rev. ed. (Jo Ann Boydston, Ed.). Carbondale: Southern Illinois University Press.

-_- . (2008c). The Later Works of John Dewey, Vol. 16, 1949-1952: Essays, Typescripts, and Knowing and the Known. (Jo Ann Boydston, Ed.). Carbondale: Southern Illinois University Press.

Fisher, R. (2008). Teaching Thinking: Philosophical Enquiry in the Classroom. 3rd ed. New York: Continuum.

Granger, D. (2006). John Dewey, Robert Pirsig, and the Art of Living: Revisioning Aesthetic Education. New York: Palgrave MacMillan.

Gratton, C. (2000). "Precision, Consistency, Implication and Inference." Thinking: The Journal of Philosophy for Children, 15(1), 30-37.

Gregory, M. (2005). "Practicing Democracy: Social Intelligence and Philosophical Practice." The International Journal of Applied Philosophy, 16(1), 161-174. 
_-_- (2002). "Are Philosophy and Children Good for Each Other?" Thinking: The Journal of Philosophy for Children, 16(2), 9-11.

- - - (2000) “The Status of Rational Norms." Analytic Teaching, 21(1), 53-64.

Gutmann, A. (1987). Democratic Education. Princeton: Princeton University Press. Hadot, P. (1995). Philosophy as a Way of Life: Spiritual Exercises from Socrates to Foucault. (M. Chase, Trans.). Malden, MA: Blackwell Publishing.

___. (2002). What is Ancient Philosophy? (M. Chase, Trans.) Cambridge: Harvard University Press.

Haynes, F., and Haynes, B. (2000). “The Development of a Conceptual Framework for Critical Thinking and Problem Solving K-12." Critical and Creative Thinking, $8(1), 15-22$.

Johnson, T. W. (1995). Discipleship or Pilgrimage? The Educator's Quest for Philosophy. Albany: State University of New York Press.

Kennedy, D. (2010). Philosophical Dialogue with Children. Lewiston, NY: The Edwin Mellon Press.

_-_- (1999). "Philosophy for Children and the Reconstruction of Philosophy." Metaphilosophy, 30(4), 338-359.

- - - (1998). "Reconstructing Childhood." Thinking: The Journal of Philosophy for Children, 14(1), 29-37.

_-_- (1994). "Helping Children Develop the Skills \& Dispositions of Critical, Creative and Caring Thinking." Analytic Teaching, 15(1), 3-16.

Lim, T. K. (2004). "Piaget, Vygotsky and the Philosophy for Children Program." Critical and Creative Thinking, 12(1), 32-38.

Lipman, M., and Sharp, A. M. (1978). "Some Educational Presuppositions of Philosophy for Children." Oxford Review of Education, 4(1).

Lipman, M. (2003). Thinking in Education. 2nd ed. Cambridge: Cambridge University Press.

_-_- (1998). “The Contributions of Philosophy to Deliberative Democracy." In D.

Evans and I. Kucuradi (Eds.), Teaching Philosophy on the Eve of the Twenty-First Century. Ankara: Editions of the Philosophical Societies of Turkey.

- - - (1996). Natasha: Vygotskian Dialogues. New York, Teachers College Press.

_-_. (1994). "Philosophy for Children's Debt to Dewey." In M. Taylor, H. Schrier, and P. Ghiraldelli (Eds.), Pragmatism, Education and Children (pp. 143-151). Amsterdam: Editions Rodopi B.V.

_-_- (1984, September). "The Cultivation of Reasoning Through Philosophy." Educational Leadership, pp. 51, 56.

Loori, J. D. (2002). The Eight Gates of Zen: A Program of Zen Training. Boston: Shambhala Publications.

Margolis, A. A. (1996). "A Comparison between the Philosophy for Children Approach and the Cultural-Historical and Activity Approaches: Psychological and Educational Foundations." In M. Lipman, Natasha: Vygotskian Dialogues. New York, Teachers College Press. 
Matsuoka, C. (2004). "Mindful Habits and Philosophy for Children: Cultivating Thinking and Problem-Solving in Children.” Thinking, 17(1-2), 54-55.

Matthews, G. (1996). Philosophy of Childhood. Cambridge, Harvard University Press. -_- . (1980). Philosophy and the Young Child. Cambridge, Harvard University Press.

Mead, G. H. (1934). Mind, Self and Society. Chicago: University of Chicago Press. Melville, M. E. (1990). "William James and the Nature of Thinking: A Framework for Elfie." Thinking, 9(1), 32-34.

Needleman, J. (1982). The Heart of Philosophy. New York: Knopf.

Nussbaum, M. (2010). Not for Profit: Why Democracy Needs the Humanities. Princeton: Princeton University Press.

Pierce, C. S. (1878). "How to Make our Ideas Clear." Popular Science Monthly, 12, pp. 286-302, retrieveded December 17, 2010, from www.peirce.org/writings/ p119.html.

Reznitskaya, A., et al. (2008). "Learning to Think Well: Application of Argument Schema Theory." In C. C. Block, et al. (Eds.), Comprehension Instruction: Research-Based Best Practices. New York: Guilford Press.

Rorty, R. (1999). Philosophy and Social Hope. New York: Penguin.

Sharp, A. M. (2009). “The Child as Critic.” In E. Marsal, T. Dobashi, and B. Weber (Eds.), Children Philosophize Worldwide: Theoretical and Practical Concepts (pp. 201-208). New York: Peter Lang Verlag.

_-_- (2004). "And the Children Shall Lead Them." International Journal of Applied Philosophy, 18(2), 177-187.

___. (1996) "Self-Transformation in the Community of Inquiry." Inquiry, Critical Thinking Across the Disciplines (Spring, 1996).

-__. (1995a) "Peirce, Feminism and Philosophy for Children." In Ronald F. Reed and John P. Portelli, (Eds.), Democracy and Education. Calgary: Detselig Enterprises, 1995.

- - _. (1995b). "Habits in the Thought of Charles S. Peirce." Critical and Creative Thinking: The Australasian Journal of Philosophy for Children, 3(1), 43-47.

_-_ . (1993). "Pierce, Feminism, and Philosophy for Children." Analytic Teaching, 14(1), 51-62.

Shusterman, Richard. (2008). Practicing Philosophy: Pragmatism and the Philosophical Life. New York: Routledge.

_-_- (2000). Performing Live: Aesthetic Alternatives for the Ends of Art. Ithaca: Cornell University Press.

_-_. (2008). Body Consciousness: A Philosophy of Mindfulness and Somaesthetics. Cambridge: Cambridge University Press.

Slade, C. (1989). “Logic in the Classroom.” Thinking: The Journal of Philosophy for Children, I(2), 14-20.

Splitter, L. J., and Sharp, A. M. (1995). Teaching for Better Thinking. Melbourne: Australian Council of Educational Research. 
Splitter, L. (1988). "A Guided Tour of the Logic in Harry Stottlemeier's Discovery." Analytic Teaching, 8(2), 71-86.

Suissa, J. (2008). "Philosophy in the Secondary School-a Deweyan Perspective." In M. Hand and C. Winstanley (Eds.), Philosophy in Schools (pp. 132-144). London: Continuum.

Suzuki, S. (2011). Zen Mind, Beginner's Mind. Boston: Shambhala Publications. Weinstein, M. (1988). "Reason and Critical Thinking." Informal Logic, 10(1), 1-20.

\section{Notes}

1. All but one of the articles published here were first presented at the 2011 American Philosophical Association Eastern Division Annual Meeting in Washington, D.C., at a session jointly sponsored by the John Dewey Society and the Institute for the Advancement of Philosophy for Children.

2. See, for example, David Granger's discussion of Dewey's critique of "the sociocultural conditions under which we have come to receive and respond to art," which involve "a tacit endorsement of the intellectual dispositions of a class-based society ... the rise of Western nationalism (furthering the desire to display the loot gathered in conquest of other nations) and the growth of modern capitalism (magnifying attitudes and practices of commodification)" (2006, p. 110).

3. It is significant that Dewey called for the cultivated naïveté of the eye and the ear as well as of thought; and it is not coincidental that Zen Buddhist philosophers also call for the cultivation of "beginner's mind" as an aspect of wisdom (Suzuki, 2011), that they frequently describe this as a return to the child's mind, and that among the contemplative practices they recommend for this cultivation are exercises in art (Loori, 2002).

4. Granger further explains: "Simply put, [the arts] can assist in reconstructing the 'static filters' of indurated habit. In making the ordinary appear extra-ordinary, the arts make us aware of the limitations of those subconscious sense-making structures that actively condition the contents and contexts of everyday experience" (2006, p. 105).

5. Kennedy further explains: "What this does for the adult who listens for the voice of the child is that, through his relationship with the child, he rediscovers his own childhood by becoming conscious of the boundaries between instinct and repression that were a result of his own childhood formation. Through becoming aware of his own 'child, he recovers himself on a higher level-through incorporating unconscious contents into consciousness. ... This in turn leads to the development of adults who experience a healthier, more creative relationship between conscious and unconscious elements of the self, and are therefore more capable of 'inquiry and creative transformation"' (1998, pp. 34-35).

6. In current programmatic and research literature phrases such as, "Philosophy for Children," "with Children and Adolescents," "Philosophy in Schools," and "Philosophy for Young People," are used interchangeably to refer to any program that engages children in philosophical dialogue-as opposed, especially, to high school courses in which philosophy is studied as an academic subject.

7. It was later published as What Happens in Art. (1967). New York: Appleton Century Crofts.

8. See www.icpic.org, retrieved August 20, 2012.

9. "The conclusions I found in Vygotsky ... showed me how to apply, specifically to the relationship between teaching and mental development, the views I had arrived at earlier 
as a result of repeatedly dipping into Pierce and Dewey, as well as more sustained examinations of Buchler" (Lipman, 1996, p. xiii).

10. Dewey writes, for instance, that "the work of art develops and accentuates what is characteristically valuable in things of everyday enjoyment. The art product . . . issues[s] from the latter, when the full meaning of ordinary experience is expressed.... A conception of fine art that sets out from its connection with discovered qualities of ordinary experience will be able to indicate the factors and forces that favor the normal development of common human activities into matters of artistic value" (1989, p. 17).

11. With regard to ethical inquiry, for instance, Lipman et al. insist that, "Students must not only be encouraged to express their beliefs . . . but to discuss and analyze them, considering the reasons for and against holding them, until they can arrive at reflective value judgments that are more firmly founded and defensible than their original preferences may have been" (1980, p. 47).

Maughn Gregory is Associate Professor in the Department of Educational Foundations at Montclair State University.

E-mail: gregorym@montclair.edu 